\title{
REFORMASI BIROKRASI DALAM ORGANISASI KEMAHASISWAAN UNIVERSITAS KEBANGSAAN BANDUNG
}

\author{
Ira Lusiawati \\ Universitas Kebangsaan \\ Email: Iralusia72@gmail.com
}

\begin{abstract}
Bureaucratic reform is an ongoing effort which at each stage provides changes or improvements to the bureaucracy for the better. The purpose of this reform is none other than to improve the quality and existence of all members, especially students of Bandung Nationality University. The purpose of this research is nothing but a measure of the implementation of the bureaucratic reform. The method is used in this research is a qualitative method so get the results that the bureaucratic reform is going as expected and the wishes of the respondents, and make students become more active and have a high sense of responsibility towards student organizations Kebangsaan University Bandung.
\end{abstract}

Keywords: bureaucratic reform, student organizations, quality

\begin{abstract}
Abstrak
Reformasi birokrasi merupakan upaya berkelanjutan yang setiap tahapannya memberikan perubahan atau perbaikan birokrasi ke arah yang lebih baik. Tujuan reformasi ini tidak lain demi meningkatkan kualitas dan eksistensi semua anggota khususnya mahasiswa Universitas Kebangsaan Bandung. Adapun tujuan diadakan penelitian ini tidak lain sebagai alat ukur pelaksanaan reformasi birokrasi tersebut. Metode yang di pakai dalam penelitian ini yaitu metode kualitatif sehingga mendapatkan hasil bahwa reformasi birokrasi ini berjalan sesuai harapan sesuai ungkapan dari hasil wawancara, dan membuat mahasiswa menjadi lebih aktif dan memiliki rasa tanggung jawab yang tinggi terhadap organisasi kemahsiswaan Universitas Kebangsaan Bandung
\end{abstract}

Kata kunci: reformasi birokrasi, organisasi kemahasiswaan, kualitas

\section{Pendahuluan}

Mahasiswa sebagai cendekiawan mempunyai tanggung jawab yang harus senantiasa dilaksanakan. Menurut (Benda, 2016) tiga tolak ukur yang menjadi dasar tanggung jawab kecendekiaan, yaitu keadilan, kebenaran, dan rasio. Pernyataan tersebut menandakan bahwa mahasiswa memiliki tuntutan sebagai generasi yang terus berupaya menegakan keadilan dan kebenaran dengan berlandaskan pada rasionalitas bangsa. Aktivitas dan gerakan mahasiswa tersebut sebagai wujud refleksi dari tanggung jawab yang mendasar pada mereka. 
Erat kaitannya dengan kondisi tersebut, perlu adanya wadah yang dapat menampung dan menyalurkan aspirasinya semisal dengan adanya organisasi di perguruan tinggi. Organisasi ini di pandang perlu demi mencapai tujuan yang sudah di tetapkan sebelumnya. Dengan kata lain, organisasi ini sebagai wadah dari sekelompok orang (group of people) yang memiliki tujuan yang sama dalam kerja sama.

Dengan adanya pemaparan diatas, menandakan bahwa pentingnya keberadaan organisasi bagi pengembangan diri mahasiswa. Hal tersebut dipertegas dengan adanya Undang-Undang Republik Indonesia Nomor 12 tahun 2012 tentang Pendidikan Tinggi pasal 77 mengenai Organisasi Kemahasiswaan.

Undang-undang tersebut mempertegas bahwa pentingnya organisasi mahasiswa berdampak terhadap kesiapan mahasiswa ketika terjun di masyarakat. Peran organisasi ini yaitu menciptakan karakter berjiwa pemimpin dan mempunyai loyalitas yang tinggi dengan keberanian, tanggung jawab dan menumbuhkan keterampilan kewarganegaraan. Idealisme yang tinggi serata potensi akademis maupun organisasi dapat tumbuh dan berkembang dengan adanya organisasi. Sebagai mahasiswa yang progresif, kreatif, dan kritis harus mampu mengambil peran tersebut.

Dengan adanya aturan tersebut maka instansi perguruan tinggi harus mempunyai inovasi birokrasi dalam menjalankan organisasi yang terus berkembang. Tujuan adanya reformasi ini tidak lain demi menjawab tantangan dan kemajuan zaman.

Reformasi birokrasi merupakan upaya berkelanjutan yang setiap tahapannya memberikan perubahan atau perbaikan birokrasi ke arah yang lebih baik. Dengan adanya reformasi diharapkan dapat diwujudkan organisasi yang baik, bersih, tertata, tanpa adanya kolusi dan nepotisme. Selain itu, diharapkan pula dapat diwujudkan pelayanan publik yang sesuai dengan harapan mahasiswa, harapan semua yang berhubungan dengan instansi perguruan tinggi dan mampu bersaing dalam dinamika global yang semakin ketat, kapasitas dan akuntabilitas kinerja birokrasi semakin baik, SDM perguruan tinggi semakin profesional, serta mind-set dan culture-set yang mencerminkan integritas dan kinerja semakin tinggi. Reformasi birokrasi mampu menciptakan birokrasi instansi terutama dalam hal pelayanan yang prima sesuai kebutuhan bersama.

Secara konseptual, birokrasi yang ideal adalah birokrasi yang profesional, yakni birokrasi yang handal dalam memberikan pelayanan, aspiratif, akuntabel, netral, dan dalam menjalankan aktivitasnya selalu dilandasi etika. Profesionalisme birokrasi menyangkut kemampuan yang dihubungkan dengan tingkat kemajuan ilmu pengetahuan dan teknologi, dalam arti kata kemampuan untuk menggunakan fasilitas teknologi modern tersebut. Secara ideal, birokrasi hanya akan bisa memberikan pelayanannya kepada semua kalangan secara adil apabila mempunyai sikap dan perilaku netral. Maksudnya, birokrasi hendaknya bertindak sebagai lembaga administrasi yang berorientasi pada pencapaian efisiensi dan efektifitas dalam setiap kegiatannya. 


\section{Metode Penelitian}

Tipe penelitian ini adalah deskriptif kualitatif. Dalam penelitian kualitatif yang terpenting adalah bagaimana menentukan informan kunci yang sarat informasi sesuai dengan fokus penelitian (Tanjung, 2007). Metode kualitatif dapat digunakan untuk mengungkap dan memahami sesuatu dibalik fenomena yang sedikitpun belum diketahui. Metode ini dapat juga digunakan untuk mendapatkan wawasan tentang sesuatu yang baru sedikit diketahui, serta dapat membantu peneliti memberi rincian yang kompleks tentang fenomena yang sulit diungkapkan oleh metode kuantitatif (Strauss \& Corbin, 2003).

\section{Hasil dan Pembahasan}

\section{Reformasi Birokrasi dalam Organisasi Kemahasiswaan Universitas Kebangsaan Bandung}

Reformasi birokrasi yang terjadi pada organisasi kemahasiswaan telah banyak membawa dampak perubahan yang sangat signifikan, tidak hanya yang bersifat struktural dan prosedural tetapi reformasi juga dilakukan kesemua lini birokrasi maupun birokratnya, seperti halnya reformasi birokrasi yang terjadi pada organisasi kemahasiswaan, begitu terlihat jelas perubahan yang terjadi, setelah dilakukan reformasi birokrasi perubahan dilakukan mulai dari refitalisasi ruangan kemahasiswaan yang dilengkapi dengan fasilitas yang nyaman bagi mahasiswa dan dosen. Untuk mengetahui peran reformasi birokrasi dalam organisasi kemahasiswaan dapat dilihat pada ulasan penelitian dibawah sebagai berikut

\section{A. Produktivitas}

Produktivitas merupakan kemampuan seorang dalam menghasilkan atau menyelesaikan suatu pekerjaan dengan hasil yang telah ditetapkan, semakin tinggi tingkat produktivitas seseorang maka semakin baik pula tingkat kinerjanya pada instansi tempatnya bertugas.

Adanya reformasi birokrasi bidang kemahasiswaan dituntut untuk lebih professional dalam menjalankan kebijaksanaan terhadap organisasi. Professionalitas yang diterapkan dengan sistem yang ketat secara berkala melalui metode Balance Score Card layaknya perusahaan. Metode ini dilakukan secara berkala tidak serta merta seperti perusahaan pada umumnya.

Hasil wawancara yang penulis lakukan dengan Rektor Universitas Kebangsaan Bandung yang mengatakan bahwa: "Dengan adanya reformasi birokrasi telah diberlakukan sistem absensi yang ketat, berarti mahasiswa dan dosen dituntut untuk hadir dan pulang kuliah sesuai waktunya, karena dengan absensi tersebut mahasiswa dan dosen tidak bisa bermain-main dengan absensi karena kehadiran mahasiswa tidak dapat diwakilkan oleh siapapun ataupun titip absen, dan apabila mahasiswa tidak hadir dan pulang sesuai jam kuliah maka akan ditindak dan diberikan sanksi yang telah ditetapkan." Dengan demikian dapat disimpulkan dengan adanya Refomasi Birokrasi tingkat kehadiran mahasiswa menjadi lebih disiplin dengan adanya sistem absensi 
berarti mahasiswa dan dosen akan mampu hadir secara lebih professional dan tepat waktu dalam menyelesaikan tugas dan tanggung jawabnya.

\section{B. Kualitas Pelayanan}

Kualitas layanan merupakan upaya pemenuhan kebutuhan dan keinginan konsumen serta ketepatan penyampaiannya dalam mengimbangi harapan pengguna jasa. Kualitas pelayanan (service quality) dapat diketahui dengan cara membandingkan persepsi para konsumen atas pelayanan yang nyata-nyata mereka terima atau peroleh dengan pelayanan yang sesungguhnya mereka harapkan atau inginkan terhadap atribut-atribut pelayanan suatu perusahaan. Pelayanan yang baik akan sangat membantu dalam rangka mempertahankan pelanggan (Kamaludin, 2019). Jika jasa yang diterima atau dirasakan (perceived service) sesuai dengan yang diharapkan, maka kualitas pelayanan dipersepsikan baik dan memuaskan, jika jasa yang diterima melampaui harapan konsumen, maka kualitas pelayanan dipersepsikan sangat baik dan berkualitas. Sebaliknya jika jasa yang diterima lebih rendah dari pada yang diharapkan, maka kualitas pelayanan dipersepsikan buruk. Kualitas layanan cenderung menjadi penting dalam menjelaskan kinerja organisasi kemahasiswaan. Banyak pandangan negatif yang terbentuk mengenai organisasi mahasiswa muncul karena ketidakpuasan mahasiswa terhadap kualitas, maka dengan adanya Reformasi birokrasi pada tubuh Universitas Kebangsaan.

Hasil wawancara yang penulis lakukan dengan Kepala Bidang Kemahasiswaan Universitas Kebangsaan Bandung, pada tanggal 26 April 2019 yang mengatakan bahwa: "Dosen dan steakholder tanggap dalam menerima dan menindak lanjuti setiap keluhan pengguna jasa bentuk keseriusan ini dapat dilihat dari disediakannya layanan pengaduan yang berfungsi sebagai tempat pengguna jasa menyampaikan keluhan melalui saran yang langsung disampaikan baik yang tertulis atau pun secara lisan, kemudian disediakan pula layanan pengaduan melalui telefon yang dapat dihubungi pada jam istirahat kuliah, kemudian pengaduan dapat dilakukan melalui pesan elektronik atau email yang dapat dikirimkan langsung pada webside yang dimiliki Universitas Kebangsaan Bandung, dan yang terakhir dibentuknya kepala bidang kemahasiswaan yang melayani pengguna jasa yang ingin bertanya dan mendapatkan informasi mengenai prosedur dan lain-lain."

Dari hasil penelitian diatas penulis menyimpulkan bahwa dengan adanya Reformasi Birokrasi fasilitas dan sarana bagi pengguna jasa untuk melakukan pengaduan ataupun keluhan semakin diperbaiki sehingga membuat semua elemen akan menjadi semakin tanggap dan sigap akan keluhan tersebut yang tujuan ahirnya adalah untuk meningkatkan kualitas pelayanan kepada mahasiswa. 


\section{Responsivitas}

Responsivitas merupakan kemampuan birokrasi untuk mengenali kebutuhan masyarakat, menyusun agenda dari prioritas pelayanan, dan mengembangkan program-program pelayanan sesuai dengan kebutuhan masyarakat dan aspirasi masyarakat. Secara singkat responsivitas disini menunjuk pada keselarasan antara program dan kegiatan pelayanan dengan kebutuhan dan aspirasi masyarakat. Responsivitas dimaksudkan sebagai salah satu indikator kinerja karena responsivitas secara langsung menggambarkan kemampuan birokrasi dalam menjalankan misi dan tujuannya, terutama untuk memenuhi kebutuhan masyarakat. Dalam hal ini karena tuntutan dari reformasi birokrasi yang mengharuskan perubahan besar-besaran terhadap birokrasi yang sudah ada agar menjadi lebih baik maka mengharuskan adanya kerjasama yang baik antara dosen dan mahasiswa juga civitas akademik dalan mencapai visi dan misi organisasi dalam memenuhi kebutuhan bersama.

\section{Responsibilitas}

Responsibilitas menjelaskan apakah pelaksanaan kegiatan birokrasi itu dilakukan sesuai dengan prinsip-prinsip administrasi yang benar dengan kebijakan birokrasi, baik yang eksplisit maupun implisit.

Hasil wawancara yang penulis lakukan dengan Wakil Rektor III pada tanggal 26 april 2019 yang mengatakan bahwa: "Pelatihan dan diklat merupakan program rutin yang dilakukan untuk mengasah kemampuan mahasiswa dan ada pula pelatihan khusus yang diberikan kepada dosen, yang tujuannya adalah untuk menambah wawasan sehingga tidak lagi canggung dalam menghadapi masalah dilapangan." Dari hasil penelitian responden rutin mengikuti pelatihan dan diklat yang diadakan, hal ini bertujuan untuk melatih kemampuan semua elemen organisasi dalam melaksanakan tugas.

\section{E. Akuntabilitas}

Hasil wawancara yang penulis lakukan dengan Wakil Rektor III pada tanggal 26 april 2019 yang mengatakan bahwa: "Setelah adanya reformasi birokrasi tidak hanya kualitas yang ditingkatkan namun sanksi juga semakin ketat sebagai alat control kepada anggota dan pengelola, sebagai contoh apabila tidak masuk, terlambat, pulang lebih awal dari jam yang ditetapkan maka diberikan sanksi."

Dapat penulis simpulkan bahwa semua mahasiswa dan dosen semakin sadar akan ketatnya control yang diberikan apabila melakukan pelanggaran yakni berupa saksi yang tegas, dimana hal ini bertujuan untuk menjaga agar semua mahasiswa dan dosen tetap maksimal.

Dari hasil penelitian tersebut responden menyatakan dengan adanya reformasi birokrasi memberikan motivasi dalam menyelesaikan tugas, hasil ini didukung dengan kutipan wawancara yang penulis lakukan dengan Wakil Rektor III pada tanggal 27 april 2019 yang mengatakan bahwa: "Reformasi birokrasi membawa dampak yang baik dalam meningkatkan motivasi karena 
reformasi birokrasi didahului dengan pemberian renumerasi yang cukup bagus sehingga menjadi lebih semangat dalam bekerja" Jadi dapat penulis simpulkan bahwa reformasi birokrasi tidak hanya semata-mata hanya mewajibkan civitas harus bekerja ekstra namun juga diberikan tunjangan sebagai timbal baiknya yang pada akhirnya diharapkan bisa meningkatkan kinerja secara maksimal.

Dari hasil penelitian diatas menyatakan bahwa civitas akademik, termasuk dosen dan mahasiswa bersedia melakukan evaluasi, hal ini merupakan sebuah keharusan yang dilaksanakan setiap bulannya dan akan dilakukan rekapitulasi pada akhir tahun untuk mengetahui nilainya untuk selanjutnya dilakukan tindakan, berupa seminar dan pelatihan-pelatihan hingga pemberian sanksi.

Walaupun hasil penelitian tentang kualitas layanan sudah sangat baik kendati demikian dari observasi yang penulis lakukan tetap ada keluhan dari pengguna jasa yang mengeluhkan layanan universitas terhadap orang tua dan mahasiswa.

\section{Peran Mahasiswa dalam Reformasi Birokrasi}

Seseorang yang telah bergabung dalam organisasi atau bisa disebut menjadi anggota dalam organisasi pasti memiliki tugas yang diemban oleh anggota tersebut. Masing-masing anggota menuturkan tugas yang mereka emban dalam organisasi adalah berpartisipasi dalam pengembangan program kerja organisasi dengan menjadi pengurus di dalam organisasi, menjadi konseptor dalam setiap kegiatan dan hanya menjadi anggota sebesar $57,00 \%$. Selain itu ada $41,00 \%$ anggota yang mengemban tugas melaksanakan program kerja organisasi seperti pengadaan sarana dan prasarana, melakukan regenerasi anggota dan melakukan koordinasi dengan anggota lain terkait pelaksanaan program kerja. Hal ini sesuai dengan yang diungkapkan oleh Schein (Muhammad, 2000) bahwa organisasi adalah suatu koordinasi rasional kegiatan sejumlah orang untuk mencapai beberapa tujuan umum melalui pembagian pekerjaan dan fungsi melalui hirarki otoritas dan tanggung jawab.

Sebesar 70,00\% anggota mengatakan mereka turut berkontribusi untuk pengembangan organisasi yang mereka ikuti seperti melakukan tugas-tugas yang telah diberikan pada saat setiap kegiatan yang diselenggarakan dan mereka memberikan waktu dan tenaga demi kelancaran pelaksanaan program kerja yang ada dalam organisasi mereka. Ada juga sebanyak $17 \%$ yang berkontribusi dalam hal pengembangan SDM yang terdapat dalam organisasi melalui cara memberikan pelatihan dan membagikan setiap ilmu yang mereka dapatkan kepada anggota yang ada dalam organisasi agar dapat bermanfaat dalam setiap kegiatan yang ada dalam organisasi. Hal ini sesuai Menurut (John M. Ivancevich, Konopaske, Robert. Matteson, 2007) bahwa Anggota organisasi sebagai penggerak operasional pada organisasi dalam perusahaan yang mana fungsi manusia yang bekerja secara individu atau kelompok dengan arahan pimpinan untuk mencapai tujuan-tujuan perusahan. 


\section{Kesimpulan}

Mengenai hasil penelitian tentang reformasi birokrasi dalam organisasi mahasiswa Universitas Kebangsaan Bandung dapat disimpulkan sebagai berikut:

1. Reformasi birokrasi pada ruangan organisasi sudah sangat baik dan sesuai harapan dari reformasi birokrasi itu sendiri hal ini dapat dilihat pada refitalisasi kantor menjadi kantor modern yang dilengkapi dengan sarana dan prasarana pendukung pelayanan, penyusunan SOP untuk kepentingan peningkatan pelayanan kepada dosen dan mahasiswa, pemberi informasi kepada mahasiswa dan wakil rektor III bertugas sebagai pengontrol dan penilai kinerja anggota agar sesuai dengan visi dan misi dari instansi itu sendiri.

2. Dengan adanya reformasi birokrasi mampu memberikan perubahan yang baik bagi kinerja anggota dan memiliki metode yang tepat dalam menilai kinerja dengan menggunakan Balance Score card layakna di perusahaan dan setiap tahun diberikan penilai. Dengan adanya remunerasi yang baik didukung dengan penataan organisasi, peningkatan disiplin dan manajemen SDM yang jelas, maka kinerja pegawai setelah reformasi birokrasi semakin baik

3. Peran mahaiswa dalam reformasi birokrasi ini sangat positif dengan adanya daya dukung dan keaktifan mahasiswa sebagai anggota organisasi. 
Ira Lusiawati

\section{BIBLIOGRAFI}

Benda, J. (2016). La trahison des clercs. République des Lettres.

John M. Ivancevich, Konopaske, Robert. Matteson, M. T. (2007). Perilaku dan Manajemen Organisasi. Erlangga.

Kamaludin, A. (2019). Hubungan Kualitas Pelayanan Terhadap Kepuasan Konsumen Pada Apotik Puji Lestari Majalengka. Syntax Literate; Jurnal Ilmiah Indonesia, 4(12), 47-55.

Muhammad, A. (2000). Komunikasi Organisasi. PT Bumi Aksara.

Strauss, A., \& Corbin, J. (2003). Dasar-dasar penelitian kualitatif. Yogyakarta: Pustaka Pelajar.

Sutrisno, H. (1988). StatistikJilid 2. Fakultas Physikologi Universitas Gajah Mada.

Tanjung. (2007). Metode Penelitian Untuk Penulisan Skripsi/Tesis, PPM. 